\title{
Relevance of brands and beef quality differentials for the consumer at the time of purchase
}

\author{
Carla Mecca Giacomazzi ${ }^{1}$, Edson Talamini ${ }^{2}$, Liris Kindlein ${ }^{3 *}$
}

\footnotetext{
${ }^{1}$ Universidade Federal do Rio Grande do Sul, Centro de Estudos e Pesquisa em Agronegócio, Porto Alegre, RS, Brazil.

${ }^{2}$ Universidade Federal do Rio Grande do Sul, Faculdade de Ciências Econômicas, Porto Alegre, RS, Brazil.

${ }^{3}$ Universidade Federal do Rio Grande do Sul, Faculdade de Veterinária, Porto Alegre, RS, Brazil.
}

\begin{abstract}
The objective of this study was to identify the purchase habits and preferences of beef consumers, their level of knowledge on brands and products with quality differentials (certifications, packaging, premium lines), and the relevance of different attributes in the purchase decision, and to group consumers according to the profile of purchase decision. The methodology consisted of using an information-collecting instrument applied to 271 beef consumers. The data collected were analyzed using descriptive statistical analyses, chi-square analysis, and correspondence analysis, relating socio-demographic profile of the respondents with the other variables collected. Chi-square and correspondence analyses showed that younger consumers with lower levels of income and education are influenced by posters and advertisements at the point of sale, unaware of differentiated and branded products, and that they do not choose branded beef at the time of purchase. Consumers over 60 years showed a more conservative purchase profile, with no influence. The most valued attributes are appearance, price, and type of cut, being brand and certifications little relevant as tools to help decide the product purchase.
\end{abstract}

Key Words: beef, consumer, purchase decision, meat brands, quality

\section{Introduction}

Understanding the behavior of an individual at the moment of food purchase, especially beef, has become complex and essential for the marketing and strategic planning of companies. This behavior is closely related to the involvement during the selection of a product. The act of being involved in the purchase is linked to the level of interest and knowledge about a particular product (Verbeke and Vackier, 2004). Furthermore, with a greater knowledge of the final consumer, companies can formulate feasible strategies in accordance with their human and financial resources and specific interests, making them more competitive and increasing their advantage in the market (De Barcellos, 2007).

The consumer may show distinct behaviors depending on the circumstances. Besides defining the target audience through market segmentation, identification, and

Received: August 12, 2016

Accepted: January 25, 2017

*Corresponding author: liris.kindlein@ufrgs.br

http://dx.doi.org/10.1590/S1806-92902017000400012

How to cite: Giacomazzi, C. M.; Talamini, E. and Kindlein, L. 2017. Relevance of brands and beef quality differentials for the consumer at the time of purchase. Revista Brasileira de Zootecnia 46(4):354-365.

Copyright (C) 2017 Sociedade Brasileira de Zootecnia. This is an Open Access article distributed under the terms of the Creative Commons Attribution License (http://creativecommons.org/licenses/by/4.0/), which permits unrestricted use, distribution, and reproduction in any medium, provided the original work is properly cited. selection of relatively homogeneous consumer groups, understanding their behavior and identifying distinct desires and expectations is vital.

As to the improvement of product quality, many actions have been carried out; however, the questions to be made are: what attributes are considered important, relevant, and fundamental for the current consumer? How to decide what and when to buy? And how this movement is understood as it has been leveraged by the different chain links related to the product diversity and new purchase options on the shelves?

Although the modern marketplace shows differentiation initiatives, such as adding value to products and market segmentation, there is no guarantee of loyalty of the consumer, culminating in the issue of products with quality differential being marketed together with lower quality ones, and affecting the credibility of the chain as a whole.

In the southern region of Brazil, beef is a product strongly linked to the eating habits of consumers, being part of their tradition; however, little information was found on the relevance of intrinsic and extrinsic attributes, among them brand and certification, in beef purchase decision of this consumer and how the informative signs (seals, certifications quality differentials) given by the industries are perceived.

The main objective of this study was to identify the purchase habits and preferences of the beef consumers, 
their knowledge on the brands and products with quality differentials (certifications, packaging and premium lines), and the most relevant attributes in the purchase decision, and group consumers according to the purchase decision profile.

\section{Material and Methods}

The study was divided into two phases: exploratory the factors influencing the decision of beef purchase - and descriptive - the research sample, with 271 beef purchasers, who, at the moment of the approach, were at the points of sale, close to the meat sector. An initial question was used to select only the individuals who consumed beef and were purchasing this product.

We considered special or premium meat cut, the product with some attributes different from other competitors, generating a sense of reward to the individual who acquires it, and whose basic premise is the highquality level (Pompeu et al., 2011). Such attributes may be a brand, certification, or seal, which allows the company to practice prices higher than the competitors (Ozório, 2003). In general, the consumer can have the information on the packing and/or seals, or quality clues (standardized appearance, price, among others).

A map of Porto Alegre, Rio Grande do Sul, Brazil (latitude -30.0277 and longitude -51.2287 30 $0^{\circ} 40^{\prime \prime}$ South, 51 $13^{\prime} 43^{\prime \prime}$ West), was used and, according to its macroregions (North, East, Center, South), the application points were defined uniformly, covering all regions. Establishments were chosen within each macroregion, including butcheries, meat markets, meat supermarkets, supermarkets, and small, medium, and large hypermarkets, besides the public market, totaling sixteen establishments. The data collection period lasted three consecutive months.

The questionnaire consisted of 19 questions (Table 1), merging open and closed questions, aiming to obtain qualitative and quantitative data (Neuman, 2009). To enable the associations between the variables, the open questions were classified seeking a pertinent grouping.

Regarding the brand attributes, considered the most important on beef purchase, a list with the following terms was provided: "packaging", "certification", "inspection", "brand", "breed", "production system", "origin", "easy to prepare", "price", "type of cut", "nutritional composition", and "product appearance". The consumers could choose one or more attributes and, after data collection, each variable was changed into binary, justifying percentages higher than $100 \%$ in the total sum of attributes.
The questionnaire was evaluated by four researchers in the area of meat quality to analyze the content and validate the tool and a pre-test was applied to verify the need of improvement and adjustments. The training of the interviewer team consisted on the reading and interpretation of all questions from the collection tool, besides a simulation approach with the consumers. This step was very important to standardize the approach to make it as uniform as possible.

At first, a descriptive analysis of the population sample according to gender, age, income, education, and family profile (number of persons at home and children under 14) was developed, including means and frequencies of database.

From the frequency distribution, the Chi-square method was used to compare the categorical variables to associate the socio-demographic characteristics of the respondents with the other variables collected (Bernués et al., 2012).

To study the relation between two categorical variables, a correspondence analysis was applied to the associations with significant differences in Chi-square test (Bernués et al., 2012). Through that methodology, we aimed at grouping the consumers interviewed according to the similarity of choices made at the time of purchase. When the value of the Chi-square test results in the rejection of null hypothesis of the independence of two variables, the frequency analysis hardly reveals the behavior observed in the data when there are various categories. In this case, the use of correspondence analysis is interesting, because it allows to represent the nature of existing relations graphically, wherein similar categories are placed close to each other. That method allows the graphical visualization of the most relevant relations of a large variable set (Carvalho and Struchiner, 1992). The association between the categories is given by their graphical proximity (Greenacre, 1981). The SPSS Statistics software, version 22, was used in the statistical analysis.

\section{Results}

The profile of the population sample was predominantly female (55\%), age group between 31 and 60 years (62.7\%), and monthly family income between four and seven minimum wages $(34.2 \%)$. As to education, higher level prevailed $(47.6 \%)$. In relation to household profile, most of them were composed of three or more members (63.5\%) and no children under 14 years old (78.6\%) (Table 2).

Regarding the habits and preferences of the individuals interviewed, $64.6 \%$ consume beef four or more times a week, most of them have no preference for the day of 
Table 1 - Questionnaire applied to beef consumers during the purchase at the point of sale

Purchase habits and consumption preferences

Variable

Category

Beef consumption frequency ${ }^{1}$

Four times a week or more

Three times a week or less

Preferred moment of the week to purchase beef ${ }^{1}$

Weekend

Week day

No preference

Habit of reading the label of the product being acquired ${ }^{1}$

No

Yes

Most important attributes at the moment of beef purchase

Packaging

Certification

Inspection

Brand

Animal race

Production system

Origin

Convenience in the preparation

Price

Type of cut

Nutritional composition

Product appearance

Habit of purchasing always the same cut of beef ${ }^{1}$

Yes

No

It depends on the occasion

How much would you pay more for a cut with quality guarantee? ${ }^{1}$

Nothing

From 1 to $10 \%$

$11 \%$ or more

Knowledge and acceptance of beef brands and differentiated products

Knowledge of the certified beef concept $t^{1} \quad$ No

Yes

Satisfaction with the beef packaging you have found at the sale point ${ }^{1} \quad$ No

Yes

Level of understanding of information available on the label ${ }^{1}$

Understands all the information on the label

Understands part the information on the label

Does not understand the information on the label

Number of beef brands the respondent knows ${ }^{2}$

None

One brand

More than one brand

What makes you choose a certain beef brand ${ }^{2}$

Nothing (Does not choose a brand)

Price

Quality/product appearance

Others $^{3}$

Knows what special or premium ${ }^{1}$ cuts are

No

Yes

Influence of posters, ads, and promotions at the sale point on the purchase decision

Influence of the point of sale on the purchase decision ${ }^{1}$

Never
Rarely
Frequently
Always

Additional variables

Gender

Age
Men and Women

Group 1: up to 30

Group 2: 31 to 60

Group 3: 61 to 89 
Table 1 (Continued)

\begin{tabular}{|c|c|}
\hline Variable & Category \\
\hline Monthly family income & $\begin{array}{l}\text { Up to } 3 \text { minimum wages } \\
\text { From } 4 \text { to } 10 \text { minimum wages } \\
\text { Above } 11 \text { minimum wages }\end{array}$ \\
\hline Education & $\begin{array}{l}\text { Elementary school } \\
\text { High school } \\
\text { College }\end{array}$ \\
\hline
\end{tabular}

the week to buy the product (75.6\%), and $55.4 \%$ read the label of the product being acquired; however, only $22.5 \%$ understand all the information contained therein. Most of the individuals in the survey are not satisfied with the packaging on the shelves $(79.7 \%$ ) and $46.9 \%$ always buy the same cut.

Almost half of the individuals interviewed (48\%) are willing to pay up to $10 \%$ more for a product with quality assurance. Promotional posters and ads in the point of sale have no influence on the purchase decision in most of the consumers, who declared never or rarely to be influenced by such situational factors ( $51.3 \%$ and $22.9 \%$, respectively) (Table 3).

Taking into account the knowledge of beef brands and differentiated products, most of the individuals understand the concept of certified beef (58.3\%) and know at least one commercial brand of this product (50.2\%). However, less than half of the individuals know what special or premium cuts are (45.8\%). Among the respondents, $49.8 \%$ consider quality and appearance as tools of choice at the moment of choosing a certain beef brand (Table 3).

From the frequencies obtained in each variable, the socio-demographic profile of the respondents with their preferences and purchase habits was related. Interaction with significant difference $(\mathrm{P}<0.05)$ were highlighted and only these associations were described herein (Table 4).

The male gender was associated to the higher frequency of meat consumption compared with the female $(75.4 \%$ vs. $55.7 \%)(\mathrm{P}<0.05)$, as well as the knowledge on certified meat $(66.4 \%$ vs. $51.7 \%)(\mathrm{P}<0.05)$. In addition, the largest quantity of beef brands known was related to men, since they showed superior knowledge in relation to one or more brands (82.8\%) compared with women $(70.5 \%)(\mathrm{P}<0.05)$.

To better characterize the sample studied, the age of the respondents was divided as follows: respondents under 30 years old, group 1; respondents between 31 and 60 years old, group 2; and from 61 to 89 years old, group 3 .

It was observed that the group 3 was associated with the lowest weekly consumption of beef compared to the groups 1 and 2 (52.2\%, 30.9\%, and 32.4\%, respectively) ( $\mathrm{P}<0.05)$, and the younger individuals showed higher consumption (69.1\%).

As to the attributes that made the respondent choose certain beef brand at the moment of purchase, individuals between 61 and 89 years old were associated with "Nothing", that is, they did not choose any beef brand $(26.1 \%)(\mathrm{P}<0.05)$. It was possible to see the proximity between this group with the option "Nothing", as well as the individuals between 31 and 60 years old with price, quality and appearance, and the youngest group with other attributes (friends indication, origin of the animal, meat tenderness, product presentation, taste) (Figure 1).

Surprisingly, as to knowledge of premium cuts, the youngest consumers (under 30 years old) were associated with no knowledge of this kind of product $(72.7 \% ; \mathrm{P}<0.05)$ (Table 4).

In relation to the influence of the point of sale in the purchase decision, most of the individuals between 31 and 60 years old showed no influence by ads, posters, or panels in the point of sale when buying beef $(58.2 \%)(\mathrm{P}<0.05)$. The correspondence analysis of this association reinforces the Chi-square test results through the proximity between ages " 31 to 60 " and "never", similarly between superior age group (61 to 89) and "rarely". With the youngest respondents (under 30), in this aspect, the purchase standard was different, being often influenced by the point of sale. It was not possible to visualize this proximity with the Chi-square test only. It was also noted that the answer "always" stood alone, far from of all age groups (Figure 1).

Regarding the knowledge of beef brands among individuals who did not know any brand, there was a strong 
association with the lowest income group (42.2\%), as well as among individuals in the group of four to 10 minimum wages and their knowledge of just one beef brand (58.7\%) and among the respondents with more than 10 minimum wages and the knowledge of more than one brand (47.9\%) $(\mathrm{P}<0.05)$. This result was very interesting, because it demonstrates that the gradual increase in the income of the respondents is significantly associated to the knowledge of a greater number of beef brands. The correspondence analysis reinforced the above mentioned: lower income level is nearer to the non-knowledge of beef brands and higher income is near the knowledge of a greater number of brands (Figure 2).

Taking into account what made the respondent choose a certain beef brand, the group that opted for no brand (option "nothing") was associated with the lower-
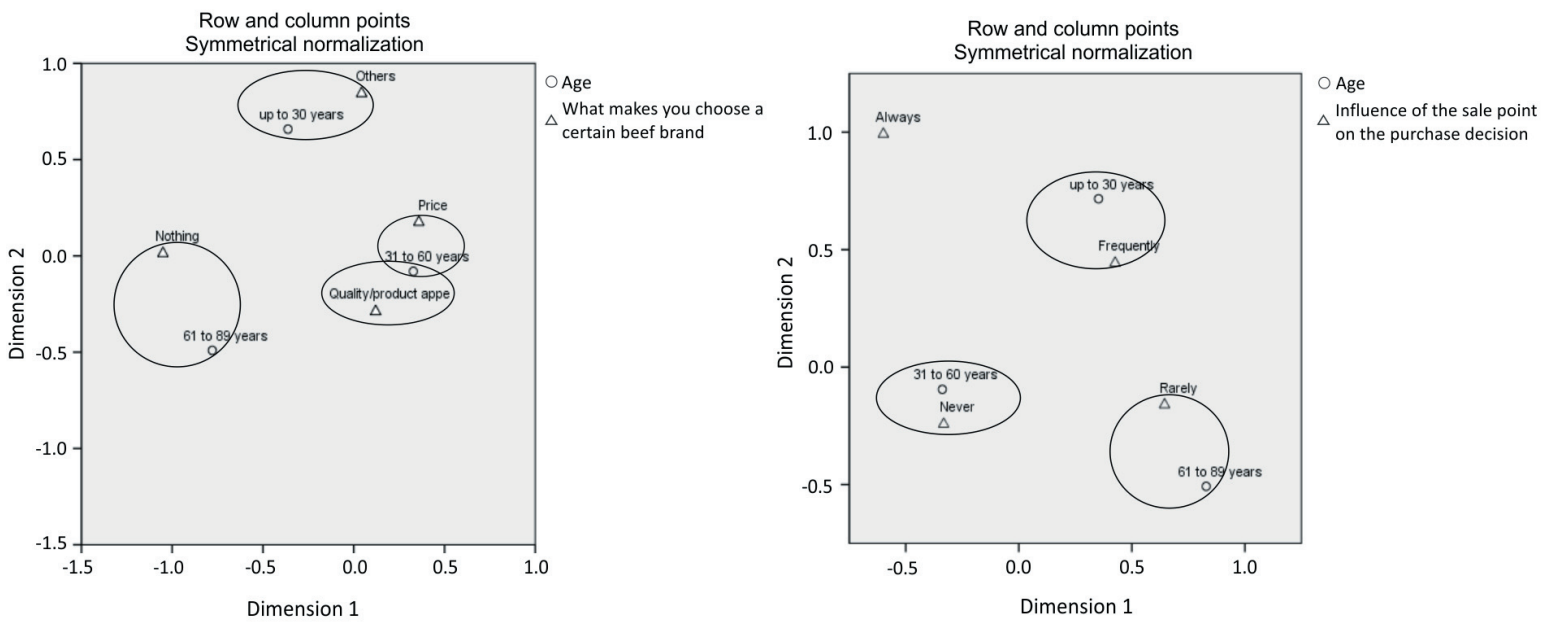

Figure 1 - Relation between "Age" and preferences and purchase habits.

Table 2 - Characterization of the sample population in the survey

\begin{tabular}{|c|c|c|}
\hline Additional variable & Number of respondents (n) & Frequency $(\%)$ \\
\hline \multicolumn{3}{|l|}{ Gender } \\
\hline Men & 122 & 45 \\
\hline Women & 149 & 55 \\
\hline \multicolumn{3}{|l|}{ Age } \\
\hline Up to 30 & 55 & 20.3 \\
\hline Between 31 and 60 & 170 & 62.7 \\
\hline 61 to 89 & 46 & 17 \\
\hline \multicolumn{3}{|l|}{ Income $^{1}$} \\
\hline Up to 3 minimum wages ${ }^{2}$ & 83 & 30.9 \\
\hline Between 4 and 10 minimum wages & 138 & 51.3 \\
\hline 11 or more minimum wages & 48 & 17.8 \\
\hline \multicolumn{3}{|l|}{ Education } \\
\hline Basic & 44 & 16.2 \\
\hline Middle & 98 & 36.2 \\
\hline University & 129 & 47.6 \\
\hline \multicolumn{3}{|l|}{ Number of persons in the household } \\
\hline Alone & 20 & 7.4 \\
\hline Two persons & 79 & 29.1 \\
\hline Three to five persons & 156 & 57.5 \\
\hline More than five persons & 16 & 5.9 \\
\hline \multicolumn{3}{|c|}{ Household classification (presence of children) } \\
\hline Without children up to 14 years old & 213 & 78.6 \\
\hline With children up to 14 years old & 58 & 21.4 \\
\hline
\end{tabular}

$\mathrm{n}$ - number of respondents. Total number of respondents was 271 .

${ }^{1}$ Two respondents did not answer.

${ }^{2}$ National minimum wage considered: R $\$ 724.00$ (base year: 2014). 
income individuals $(21.7 \%)$; the price was associated to the group with income between 4 and 10 minimum wages $(29 \%)$ and the quality and appearance were associated with higher-income respondents $(77.1 \%)(\mathrm{P}<0.05)$. Such disparity reveals that higher-income consumers are more concerned with the qualitative attributes of the product they purchase, possibly due to the financial condition of choosing products with the best quality perceived. It is also interesting to observe that even among the lower-income respondents, $42.2 \%$ are concerned with the "quality and appearance", a percentage that is superior to the option "price" $(25.3 \%)$; however, this association is not proven by the correspondence analysis (Table 4).

Graphically (Figure 2), the proximity between the level of income up to three minimum wages and "nothing" is perceived (no option for brand); for income between 4

Table 3 - Frequency distribution ( $\mathrm{n}$ and percentage) of the variables collected through the collection tool applied to beef consumers

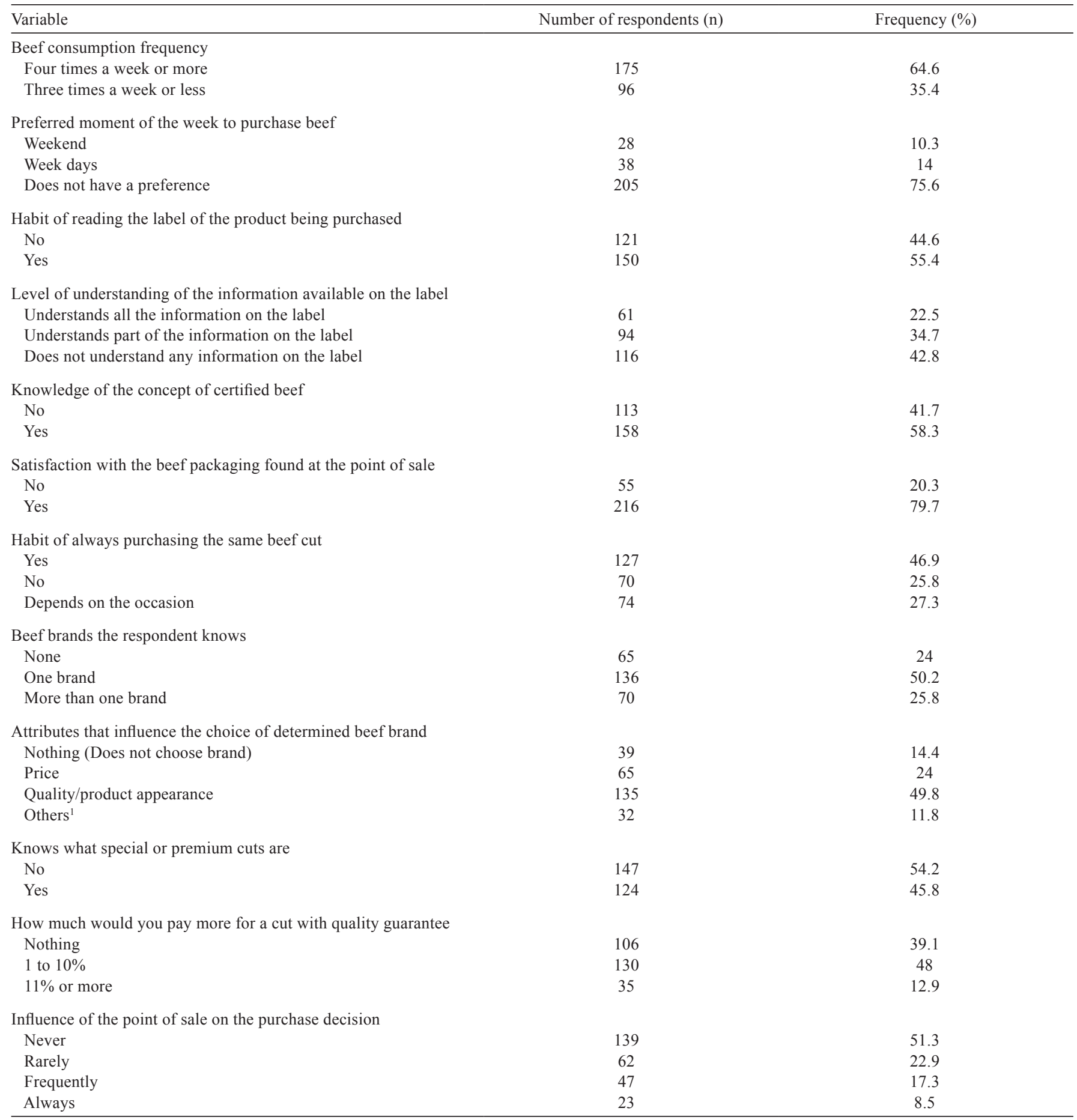

\footnotetext{
${ }^{1}$ Indication of friends, animal origin, tenderness, product presentation, and taste.
} 


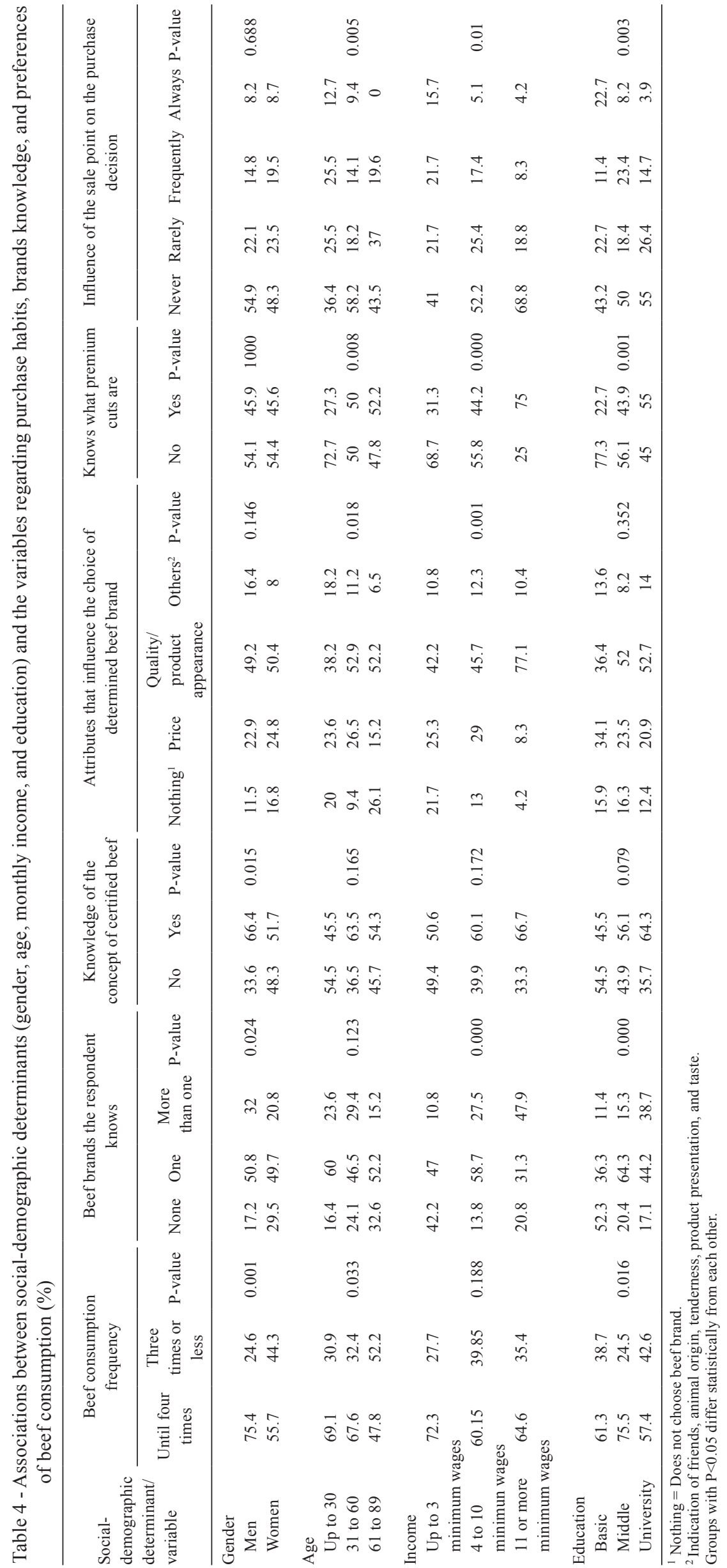


and 10 minimum wages, the brand is chosen according to a category "price"; and above 11 minimum wages, the brand is chosen according to the appearance and quality of the product. Similarly, higher-income respondents were strongly associated to the knowledge of the concept of premium cuts, in contrast to low-income respondents (75\% vs. $31.3 \% ; \mathrm{P}<0.05$ ) (Table 4$)$.

As to the influence of posters, ads, and/or panels in the point of sale on purchase decision, individuals with income up to three minimum wages were associated with being always influenced by those tools $(15.7 \%)$ $(\mathrm{P}<0.05)$ compared with the higher-income respondents, who were associated with never having their decision interfered by such tools $(68.8 \%)(\mathrm{P}<0.05)$. This relation can be graphically reinforced by the proximity between the category "more than 10 minimum wages" and "never", "up to three minimum wages" and "always" (Figure 2).

In relation to education, the group of "higher" education-level respondents showed lower frequency of weekly beef consumption $(42.6 \%$; $\mathrm{P}<0.05)$ (Table 4). In the other variables, income and education had similar associations: education increase was related to the knowledge of branded products. Only income had direct association with education, which was not observed to gender and age.

Among the respondents who said they know more than one beef brand, most of them have higher education $(38.8 \%)(\mathrm{P}<0.05)$. It is noteworthy that the correspondence analysis graph clearly shows this association: basiclevel respondents were near "no brand", medium-level respondents near "one brand", and the "higher-level ones near "more than one brand" (Figure 2).

It was also possible to associate lower education levels (basic level) with no knowledge of the special cuts (77.3\%) $(\mathrm{P}<0.05)$ and with the option "always" in the influence of posters and ads in the point of sale on purchase decision $(22.7 \%)(\mathrm{P}<0.05)$. As to the last association, the graphic representation clearly elucidates the association between the categories (Figure 2).

No significant associations were observed between the household profile and the variables studied (Table 5).

The attributes considered the most important, that is, the most influential at the moment of the purchase of beef were "product appearance" (75.6\%), "price" (72.3\%), and "type of cut" (60.1\%), followed by "easy to prepare" (22.1\%), “origin” (19.9\%), "packaging” (18.8\%), and "inspection" (17.3\%). The production system $(2.6 \%)$, breed (4.8\%), and nutritional composition of the cut ( $8.9 \%)$ were 
the least mentioned as important and having influence at the moment of purchase. The attributes "brand" (12.9\%) and "quality control stamp" (13.3\%) were little valued by the consumers as decision tools at the moment of the product purchase, proving to be of little relevance.

\section{Discussion}

Men showed higher level of knowledge on the meaning of certified meat (51.3\%) compared with women $(48.7 \%)$. This result contrasts with the study carried out by Velho et al.
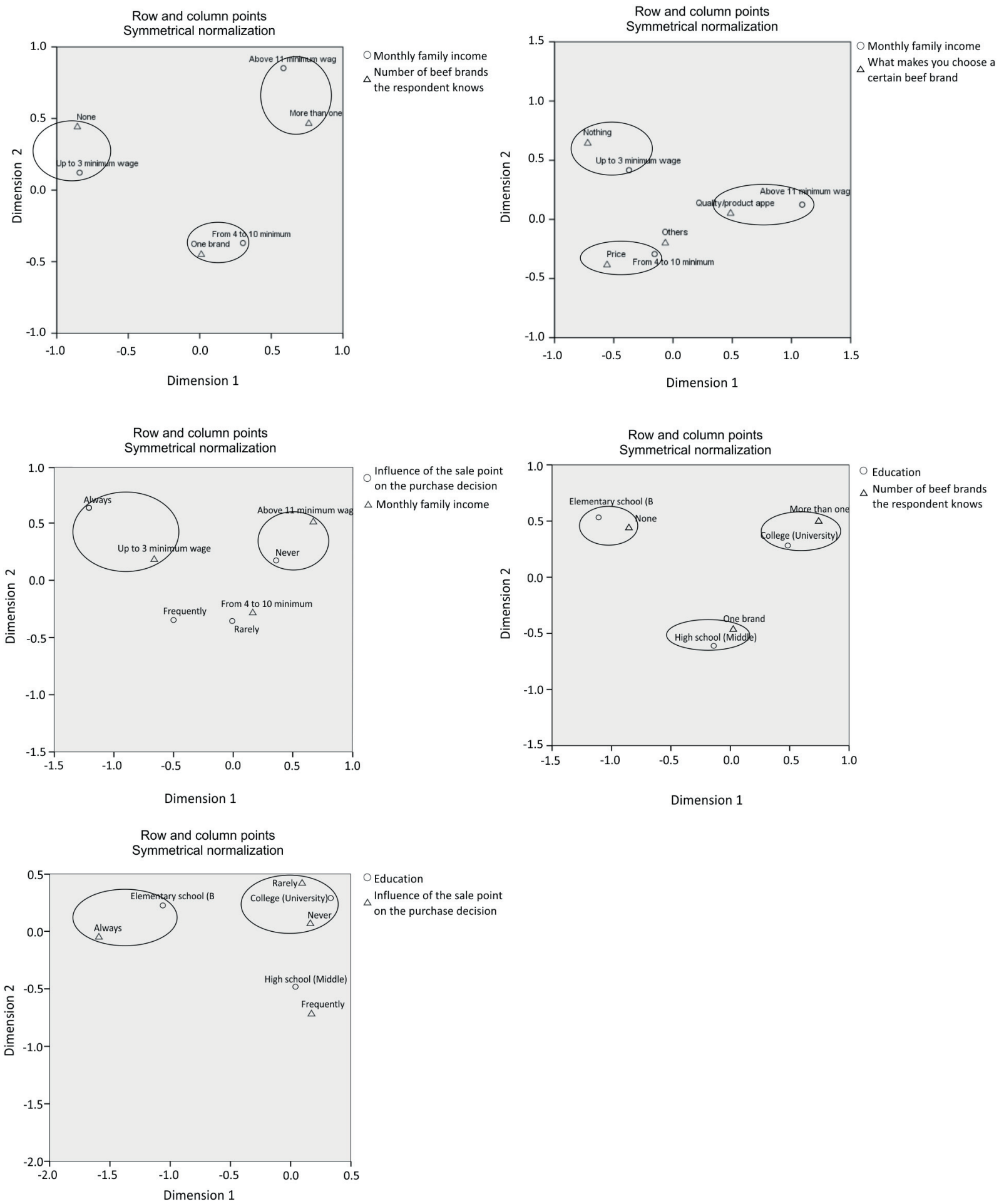

Figure 2 - Relation between "Monthly family income" and "Education" and preferences and purchase habits. 
(2009) in Porto Alegre, Rio Grande do Sul, Brazil, in which most women (64.2\%) knew the meaning of certified meat compared with men (55.2\%).

In a research developed by Yen etal. (2008), investigating the knowledge of the consumer and the influence of sociodemographic factors in the meat consumption, men showed higher levels of meat consumption than women, showing a decline in consumption according to age.

The male gender also showed greater knowledge of beef, which can be related to the regional habit of consumption of this product, like having barbecue in special occasions and weekends, when predominantly men choose and purchase the product.

Teixeira (2013), analyzing the profile of beef consumers in Porto Alegre, like the results of the present study, observed that there is a trend of the male consumers having greater knowledge about the types of certifications, although women are more demanding when buying the product. The author also verified that women showed lower frequency of beef consumption compared with men.

Older-age respondents (61 to 89 years old) showed lower frequency of beef consumption, which may be related to the dissemination of possible adverse effects of red meat to health and because it is a more traditional public, who buys food having convictions already acquired. Moreover, they were not influenced by external factors when buying this product. These findings show that these consumers have pre-established opinions and concepts and a more traditional habit of consumption, not showing interest in trying out different products. The difficulty these consumers have in chewing beef, due to its texture homogeneity, may be another factor explaining the lower frequency of consumption. Research demonstrate that only $17.5 \%$ of the elderly are able to chew meat, such as beef. (Brunetti et al., 1998; Silva and Goldenberg, 2001).

The non-knowledge of premium products by the consumers under 30 years old were surprising, since, in general, this consumer group has more interest and easy access to different media. This fact may suggest that the promotion of this kind of product is not being valued or efficiently transmitted to these consumers.

The monthly family income and education showed to be related and their associations with the other variables had a similar behavior as to the knowledge improvement according to the education level increase. A significant difference was not observed between the income and frequency of beef consumption of respondents, differently from findings of other authors (Schlindwein and Kassouf, 2006; Coelho et al., 2009; Pes et al., 2012; Kirinus et al., 2013; Teixeira, 2013). Kirinus et al. (2013) observed a trend of increasing beef consumption as the purchasing power of the consumer increases. Schlindwein and Kassouf (2006) observed that family income increases the probability of consumption and the expense with beef purchase, besides declaring that a $10 \%$ increase in the family income increases expenses with beef $(2.8 \%)$

Similarly, Pes et al. (2012) stated that the income increase generates increase in the consumption of protein food. Coelho et al. (2009) exemplifies that the income increase tends to increase the household consumption of products such as prime beef. Such disparity may be associated to a change in the behavior of the higher-income and higher-education consumer, who is aware of the appeals of "healthy life" and may be influenced by media and NGO (non-governmental organization) information, which, in the last years have presented a negative positioning in relation to beef. Teixeira (2013) also verified that the higher-income and higher-education respondents had greater knowledge on the kind of beef certifications. That author concluded that the education level, monthly family income, gender, and age were the factors that most influenced the consumer choices. These findings agreed with this research as to the sample studied.

It was observed that the product appearance, price, and kind of cut were the attributes most cited by the consumers as important in the decision of beef purchase and attributes related to brand and certification were poorly valued. These findings differ from studies developed by other authors in the so-called "more advanced" markets. In a survey conducted by Lim et al. (2013), it was found that the American consumers were willing to pay more for meat with sensorial and sanitary quality guarantee.

As to products with quality guarantee, certification, and origin labels, Loureiro and Umberger (2003, 2005, 2007) detected that the American consumers would be willing to pay more for meat. However, in a meta-analysis study developed with different agricultural products, Verlegh and Steenkamp (1999) found no significant difference in the effect of a certification in the purchase intention.

The results found in the present study may be related to a pattern of more conservative consumption by the respondents, who will decide what product to buy based on visual observation and pre-established beliefs and the presence of a seal or brand is not interesting and sufficient to significantly influence their decision.

Studies using correspondence analysis as a differentiation tool of consumer groups according to their choices and preferences at the moment of beef purchase were not found in the literature. It was possible to divide the consumers into distinct groups, according 
Table 6 - Consumer groups according to their preference of purchase and knowledge of differentiated products

\begin{tabular}{lll}
\hline $\begin{array}{l}\text { Youngsters } \\
\text { Lower income } \\
\text { Lower education }\end{array}$ & $\begin{array}{c}\text { Higher income } \\
\text { Higher education }\end{array}$ & Elderly, independent of income and education \\
\hline Influenced by point of sale in the purchase decision & $\begin{array}{l}\text { Not influenced by point of sale at the moment } \\
\text { of purchase } \\
\text { Know more than one beef brand }\end{array}$ & $\begin{array}{l}\text { Little or no influence of point of sale at the } \\
\text { moment of purchase }\end{array}$ \\
Do not know beef brands & $\begin{array}{l}\text { Luality and appearance are tools for choosing } \\
\text { Do not know premium products }\end{array}$ & Do not choose branded products \\
\hline Do not choose branded products & & \\
\hline
\end{tabular}

Youngsters: up to 30 years old; lower income: up to 3 minimum wages; lower education: basic level; higher income: 11 or more minimum wages; higher education: superior level; elderly: 61 to 89 years old.

to the proximity between the variables related to their choices at the moment of purchase (Table 6). Younger consumers (under 30 years old), with lower income (up to 3 minimum wages) and lower level of education (elementary) are influenced by the presence of posters and ads at the point of sale, do not know premium and branded products, and do not choose these products at the moment of purchase, in contrast to higher-education and higher-income consumers. The elderly were grouped independently of income and education, showing a more conservative purchase style, with little or no influence of extrinsic attributes such as brand and point of sale.

\section{Conclusions}

It can be verified that consumption frequency of beef is higher among men who has greater knowledge of certified beef with quality differentials, also having greater knowledge on beef brands available in the market. Respondents between 61 and 89 years old show lower frequency of consumption and are not influenced by external and situational factors at the time of purchase. The youngsters show little knowledge on the meaning of premium cuts. Higher-income and higher-education consumers show greater knowledge of branded products and quality certifications and tendency to value differential features in the beef they are purchasing, being a potential consumer niche that should be the target of industries and commerce. Almost half the respondents who look for branded meat have quality and appearance as choice tools at the time of purchase. The most valued attributes at the time of purchase are the product appearance, price, and cut and the least are the production system, breed, and nutritional composition of the product. The brand and the certification seals are little relevant as tools to help on the decision to buy beef.

\section{Acknowledgments}

This study was supported by the Coordenação de Aperfeiçoamento de Pessoal de Nível Superior (CAPES).

\section{References}

Bernués, A.; Ripoll, G. and Panea, B. 2012. Consumer segmentation based on convenience orientation and attitudes towards quality attributes of lamb meat. Food Quality and Preference 26:211-220.

Brunetti, R. F.; Montenegro, F. L. B. and Manetta, C. E. 1998. Odontologia geriátrica no Brasil: uma realidade padrão novo século. Atualidades Geriátricas 3:26-29.

Carvalho, M. S. and Struchiner, C. J. 1992. Análise de correspondência: uma aplicação do método à avaliação de serviços de vacinação. Caderno de Saúde Pública 8:287-301.

Coelho, A. B.; Aguiar, D. R. D. and Fernandes, E. A. 2009. Padrão de consumo de alimentos no Brasil. Revista de Economia e Sociologia Rural 47:335-362.

De Barcellos, M.D. 2007. Beef lovers: um estudo cross-cultural sobre o comportamento de consumo de carne bovina. Tese (D.Sc.). Universidade Federal do Rio Grande do Sul, Porto Alegre, RS, Brazil.

Greenacre, M. J. 1981. Pratical Correspondence analysis. p.119-146. In: Interpreting multivariate data. John Wiley, New York.

Kirinus, J. K.; Fruet, A. P. B.; Klinger, A. C. K.; Dörr, A. C. and Nörnberg, J. L. 2013. Relação entre faixas de renda e o perfil dos consumidores de carne bovina da região sul do Brasil. Revista Monografias Ambientais 12:2776-2784.

Lim, K. H.; Hu, W.; Maynard, L. J. and Goddard, E. U. S. 2013. Consumers' preference and willingness to pay for country-oforigin-labeled beef steak and food safety enhancements. Canadian Journal of Agricultural Economics 61:93-118 doi: 10.1111/j.17447976.2012.01260.x

Loureiro, M. L. and Umberger, W. J. 2003. Estimating consumer willingness to pay for country-of-origin labeling. Journal of Agricultural and Resource Economics 28:287-301.

Loureiro, M. L. and Umberger, W. J. 2005. Assessing consumer preferences for country-of-origin labeling. Journal of Agricultural and Applied Economics 37:49-63.

Loureiro, M. L. and Umberger. W. J. 2007. A choice experiment model for beef: What US consumer responses tell us about relative preferences for food safety, country-of-origin labeling and traceability. Food Policy 32:496-514. 
Neuman, W. L. 2009. Social research methods: qualitative and quantitative approaches. 7th. ed. Pearson, Toronto.

Ozório, L. M. 2003. Avaliação de marcas. Dissertação (M.Sc.). Universidade Federal do Rio de Janeiro, Rio de Janeiro, RJ, Brazil.

Pes, D. A.; De Figueiredo, M. G. and Figueiredo, A. M. R. 2012. Análise econométrica da oferta e demanda de carne bovina. Revista de Economia da Universidade Estadual de Goiás 8:54-73.

Pompeu, B.; Santos, J. and Sato, S. 2011. A segmentação, o premium e o Roberto Damatta. Revista Pensamento \& Realidade 26:134-151.

Silva, L. G. and Goldenberg, M. 2001. A mastigação no processo de envelhecimento. Revista CEFAC-Speech, Language, Hearing Sciences and Education Journal 3:27-35.

Schlindwein, M. M. and Kassouf, A. L. 2006. Análise da influência de alguns fatores socioeconômicos e demográficos no consumo domiciliar de carnes no Brasil. Revista de Economia e Sociologia Rural 44:549-572.
Teixeira, J. L. 2013. Perfil do consumidor de carne bovina em Porto Alegre-RS. Universidade Federal do Rio Grande do Sul, Porto Alegre, RS, Brazil.

Verbeke, W. and Vackier, I. 2004. Profile and effects of consumer involvement in fresh meat. Meat Science 67:159-168. doi: 10.1016/j.meatsci.2003.09.017

Velho, J. P.; Barcellos, J. O. J.; Lengler, L.; Elias, S. A. and Oliveira, T. E. 2009. Disposição dos consumidores porto-alegrenses à compra de carne bovina com certificação. Revista Brasileira de Zootecnia 38:399-404.

Verlegh, P. W. J. and Steenkamp, J. B. E. M. 1999. A review and meta-analysis of country-of-origin research. Journal of Economic Psychology 20:521-546.

Yen, S. T.; Lin, B. and Davis, C. G. 2008. Consumer knowledge and meat consumption at home and away from home. Food Policy 33:631-639. 